\title{
Schortinghuis Appointed Assistant Deputy Minister
}

S. W. (Bill) Schortinghuis, Netherlands-born chief projects engineer, has been appointed Assistant Deputy Minister of Mines and Natural Resources for Manitoba, Hon. F. C. Bell, Minister of the Department, announced recently. The Deputy Minister is J. G. Cowan.

Syze Wilto Schortinghuis, 51, came to Canada at the age of 13 . He was educated at Kelvin High School 1921-24, and at Colorado College 1924-28, where he won his B.Sc. in forestry.

He was with the CNR survey branch from 1928 to 1930 and ran levels on the Hudson Bay Railway location.

In 1930, when the Province took over jurisdiction of resources from the Federal government, he joined the Provincial Mines and Natural Resources Department as a forester and has watched-and helped-it grow to the organization it is today.

He worked in Winnipeg and Dauphin, and in 1932 was forester in charge of the Whiteshell Reserve when it was first being developed as a provincial playground. Relief work camps, he recalled, were set up there, and 500 men cleared lake areas near the narrow, gravelled No. 1 Highway that had just been built.

Mr. Schortinghuis served with the Royal Canadian Engineers during the war in England, North Africa and Northwest Europe. He commanded the First Canadian Equipment Company, RCE, with the rank of major.

On his return in 1945, he became chief of forest protection. In 1951 he was appointed chief projects engineer.

$\mathrm{He}$ is a member of the Inter-Departmental Technical Committee which deals with engineering matters of a Federal-Provincial nature. $\mathrm{He}$ is secretary of the Deputies' Committee.

Mr. Schortinghuis has worked closely with forest protection researchers and officials and has had a great deal to do with setting up the Pasquia Land Reclamation program. He is married, has one son, and lives at 1042 Grosvenor Avenue, Winnipeg.

\section{Compressed AIR KeEPS Water ICE-Free}

Many sawmills and paper mills in Sweden are using a new development in compressed air to keep waterways free of ice throughout the winter. An anti-freeze bubbler system with an AR3 compressor supplies air to a plastic pipeline laid along the bottom of the pond. Air bubbles released through the perforated pipe bring warmer water from the bottom to the top keeping the log pond free of ice and permitting year-round operations. Interesting applications of this system have also proved effective on ferry routes, slipways and shipyards. Similar systems are being introduced in Canada by Atlas Copco Canada Ltd., Montreal Airport, Quebec. 